\title{
Regionalne i rodne razlike u vrijednosnim stavovima srednjoškolaca u dvjema hrvatskim županijama: tranzicija, modernizacija i promjene vrijednosti
}

\author{
Saša PUZIĆ, Petar BEZINOVIĆ \\ Institut za društvena istraživanja u Zagrebu \\ puzic@idi.hr,petar@idi.hr
}

\begin{abstract}
U tekstu se postavlja pitanje jesu li društvene posljedice »prijelaza u kapitalizam« (društveno i ekonomsko raslojavanje, nepostojanje društvenog konsenzusa o poželjnim društvenim vrijednostima i dr.) utjecale na modernizacijsko zaostajanje hrvatskoga društva na vrijednosnoj razini. Za odgovor na ovo pitanje istražuje se kompatibilnost vrijednosnih orijentacija učenika srednjih škola socijaliziranih u tranzicijskom razdoblju u Hrvatskoj s vrijednosnim tipovima karakterističnim za Inglehartov model modernizacije vrijednosti, uključujući razlike prema rodu i regionalnoj razvijenosti. Istraživanje vrijednosnih orijentacija provedeno je na reprezentativnom uzorku od 3471 učenika iz dviju hrvatskih županija (Ličkosenjska i Primorsko-goranska županija). Pritom je najprije izračunata hijerarhija ispitanih vrijednosti i njihova faktorska struktura, nakon čega su dvosmjernim analizama varijance ispitane regionalne i rodne razlike u vrijednostima učenika. Rezultati pokazuju da srednjoškolci socijalizirani u tranzicijskom razdoblju u Hrvatskoj prihvaćaju širok raspon vrijednosnih orijentacija, što podupire tezu da su se modernizacijski procesi u tranzicijskom razdoblju u Hrvatskoj odvijali na više kvalitativnih razina. Testiranje značajnosti razlika među različitim podskupinama (regija x spol) pokazuje da razvojni čimbenici utječu na promjene vrijednosnih stavova mladih, no da kulturno posredovan efekt roda relativizira njihov utjecaj. Autori opisano stanje objašnjavaju trajnom relevantnošću rodnih podjela u društvu koje ni u uvjetima suvremenih društvenih promjena ne gube na važnosti.
\end{abstract}

Ključne riječi: tranzicija, modernizacija, mladi, vrijednosti, regionalna razvijenost, rodne podjele, pluralizacija

\section{Uvod}

Govoriti o vrijednostima mladih znači na specifičan način govoriti o vrijednostima društava u kojima mladi žive i odrastaju. Gornja fraza (»na specifičan način«) aludira na činjenicu da mladi kao društvena skupi- 
na $^{1}$ predstavljaju »izrazito senzibilan segment populacije« (Ilišin i Radin, 2002) čije promjene vrijednosnih stavova nerijetko predstavljaju najavu odgovarajućih promjena u danom društvu (Leburić i Tomić-Koludrović, 1996). ${ }^{2}$ No iako su, primjerice, naglašena senzibilnost i prijemljivost za novo, pop-kultura ili određeni vidovi društvenog nonkonformizma neke od karakteristika životnih stilova mladih i njihova zajedničkoga društvenog položaja, mlade također obilježavaju i društvena raslojenost i podjele sukladne društvu čiji su oni dio (Čulig, Fanuko i Jerbić, 1982; TomićKoludrović i Leburić, 2001). U tom smislu, osim što zauzimaju specifičan društveni prostor, mladi istodobno predstavljaju heterogenu društvenu skupinu unutar koje se prelamaju društveni konflikti i objektivne društvene proturječnosti.

Kad je riječ o proturječnostima u suvremenom hrvatskom društvu, posebno se važnim pokazao proces tranzicije ili prijelaz od jednopartijskoga socijalističkog prema višepartijskom i kapitalističkom društvenom uređenju (usp. Karajić, 2000; Županov, 2002; Maldini, 2005). Ovaj se proces tipično shvaća kao »nadoknađivanje« modernizacijskih zaostataka nekadašnjih socijalističkih društava (promjene institucionalnih i gospodarskih struktura i transformacija kulturnog sklopa) s normativnim ciljem uspostave demokratskoga tržišnog društva (Cifrić, 1996). U Hrvatskoj se tranzicija isprva odvijala u ratnim uvjetima, što je, u usporedbi s drugim tranzicijskim zemljama, dodatno zaoštrilo negativne društvene posljedice »prijelaza u kapitalizam« (ekonomsko i društveno raslojavanje) te dodatno pogodovalo politički poticanim procesima društvene retradicionalizacije. ${ }^{3}$ Zaoštravanje tranzicijskih

\footnotetext{
${ }^{1} \mathrm{U}$ sociološkom smislu pojam mladosti označava fazu u psihofizičkom razvoju pojedinaca između djetinjstva i odraslosti (otprilike od 14.-15. do 30.-35. godine), koja je vezana uz ulazak u seksualnu zrelost (biološki kriterij). Biološko definiranje mladosti po pravilu se dopunjava društvenim kriterijima, pa se tako pojam mladosti produžava na "period u životu osobe kada je društvo u kojem ta osoba funkcionira prestaje smatrati djetetom, a ne pruža joj puni status, uloge i funkcije odrasloga« (Hollingshead, prema Čulig, Fanuko i Jerbić, 1982: 28).

${ }^{2}$ Objašnjenje za ovo nalazimo u sociopsihološkim i povijesnim razlozima: s jedne strane mladi su, uslijed nedovršenog procesa socijalizacije, u većoj mjeri izloženi djelovanju okoline i društvenim promjenama, dok istodobno, pojava omladine kao zasebne društvene skupine predstavlja izravnu posljedicu društvene modernizacije: moderni industrijski razvoj dovodi do ustanovljavanja masovnog školovanja uslijed čega dolazi do odvajanja mladih od svijeta rada i do osiguravanja društvenih pretpostavki za oblikovanje zasebnih Životnih stilova (Ilišin i Radin, 2002; Županov, 2002).

${ }^{3}$ Fenomen društvene retradicionalizacije razumijemo u kontekstu politički induciranog et-
ničkog nacionalizma, kojim su političke elite mobilizirale javnost i uz pomoć kojeg su se
ideološki legitimirale (uspostavljanjem odmaka od socijalističke ideologije i prakse odno-
sno »drugih« etnija-nacija) (Galić, 2000; Ilišin, 2002).
} 
procesa pridonijelo je karakterističnom »moralnom vakumu« (Brunnbauer, 2000), odnosno činjenici da odbacivanje vrijednosti staroga socijalističkog poretka nije pratila uspostava novoga društvenog konsenzusa oko poželjnih liberalno-demokratskih vrijednosti (Ilišin, 2002). Posljedica potonje konstelacije bila je svojevrsna anomija (Županov, 1995) koja je osobito pogodila mladu populaciju u njezinom prijelazu u svijet odraslih. U tom se svjetlu mogu tumačiti i rezultati istraživanja mladih u Hrvatskoj devedesetih godina 20. stoljeća, koji pokazuju nepovjerenje prema društvenim institucijama, osobito onim političkim, kao i sve izraženije zastupanje vrijednosti privatnosti i individualne afirmacije (Radin, 2002, 2007). Zbog svega navedenog tranzicijska se socijalizacija mladih odvijala u uvjetima razmjerne socijetalne »napetosti« u kojoj su »institucije, procesi i društvene norme koje su olakšavale prelazak u svijet odraslih oslabljene, onesposobljene ili su u procesu temeljite preobrazbe« (Ilišin i Radin, 2002: 15).

Usprkos negativnoj društvenoj konotaciji, naznačeni sociokulturni procjep u kojemu se našla mlada generacija može imati određenu sociološku »vrijednost«. Točnije, okolnost da su mladi kroz tranzicijske promjene prolazili u svom formativnom razdoblju, tj. $u$ razdoblju u kojem se vrijednosti socijaliziraju i učvršćuju, omogućuje da se promjene društvenih vrijednosti zahvate $u$ »čišćem« obliku nego što bi to bio slučaj kod starije populacije (Inglehart i Baker, 2000; Tomić-Koludrović i Petrić, 2007). Pitanje koje se u tom sklopu može postaviti je jesu li opisane regresivne (retradicionalizacija) i anomijske pojave (nepostojanje općedruštvenog konsenzusa o poželjnim društvenim vrijednostima) utjecali na modernizacijsko zaostajanje hrvatskog društva na vrijednosnoj razini. Kako bi se približili odgovoru na ovo kompleksno pitanje, u tekstu što slijedi pokušat će se utvrditi postoje li, usprkos opisanim regresivnim i anomijskim pojavama iz razdoblja tranzicije, određeni obrasci u vrijednosnim orijentacijama ${ }^{4}$ srednjoškolaca u tranzicijskoj Hrvatskoj koji bi korespondirali s vrijednosnim obrascima u suvremenim razvijenim društvima. U tu svrhu (1) daje se prikaz središnjih teorijskih pretpostavki vezanih uz promjene društvenih vrijednosti pod utjecajem modernizacije kao i osvrt na istraživanja društvenih vrijednosti u tranzicijskom razdoblju u Hrvatskoj; (2) s obzirom na središnju važnost

\footnotetext{
${ }^{4}$ Vrijednosti pritom promatramo kao »relativno stabilne, opće i hijerarhijski organizirane karakteristike pojedinca (dispozicije) i skupina (elementi društvene svijesti), formirane međusobnim djelovanjem povijesnih, aktualnodruštvenih i individualnih čimbenika, koje zbog tako pripisane poželjnosti, usmjeravaju ponašanje svojih nositelja k određenim ciljevima« (Pantić, 1977: 277; usp. Giordan, 2007). Za razliku od pojedinačnih vrijednosti koje su usmjerene na ciljeve koje pojedinac intenzivno i kontinuirano želi ostvariti, vrijednosne orijentacije shvaćamo kao opće modele ponašanja u funkciji ostvarivanja pojedinih vrijednosti (Radin, 1988).
} 
rodnih uloga unutar tradicionalističkog vrijednosnog sklopa (Inglehart i Baker, 2000) u drugom se koraku opisuju obrasci rodnih uloga u Hrvatskoj prije i u razdoblju tranzicije, (3) te se u konačnici analizira struktura vrijednosnih orijentacija »tranzicijskog« uzorka srednjoškolaca u dvije hrvatske županije, kao i razlike u vrijednosnim orijentacijama između djevojaka i mladića u manje razvijenoj (Ličko-senjskoj) i razvijenijoj (Primorsko-goranskoj) županiji.

\section{Teorija modernizacije i društvene vrijednosti u Hrvatskoj}

Iako su suvremeni zastupnici teorije modernizacije ${ }^{5}$ oprezniji od svojih prethodnika $\mathrm{u}$ isticanju tehnološke i moralne superiornosti zapadnjačkog načina života kao univerzalnog modela, teza da ekonomski razvoj proizvodi dalekosežne društvene i kulturne posljedice i dalje spada među temeljne postulate ovoga teorijskog pristupa (Inglehart i Baker, 2000). U tom su smislu osnovne pretpostavke društvenoga razvoja sljedeće: tehnološke promjene proizvode diverzifikaciju zanimanja i profesionalnu specijalizaciju, paralelno se povećava opća razina urbanizacije, obrazovanosti, prihoda i društvenog bogatstva, što, u konačnici, vodi (nenamjeravanim) promjenama u društvu i kulturi - od razvoja civilnog društva, demokratskih institucija i masovne političke mobilizacije, preko promjena u obiteljskim odnosima, rodnim ulogama i seksualnim normama, do sekularizacije i racionalizacije u svim sferama društva (Parsons, 1991; Inglehart i Welzel, 2007).

Važno je napomenuti da opisani model društvenih promjena predstavlja idealan tip, te da su u različitim društvenim kontekstima mogući različiti modernizacijski putovi (Karajić, 2000). O tome govore Sztompka, Inglehart i drugi neomodernisti kada naglašavaju da modernizacijski model zapadnoeuropskih društava nije nužno jedini takav model (Sztompka, 1993; Inglehart, 1997). No usprkos mogućim razvojnim diskontinuitetima i di-

\footnotetext{
${ }^{5}$ Klasična teorija modernizacije opisuje i objašnjava procese društvene promjene karakteristične za prijelaz od tzv. tradicionalnih nerazvijenih društava prema razvijenim modernim društvima (Armer i Katsillis, 2000). Fokus je najčešće na stupnju ekonomskog razvoja izražen kroz indikatore kao što su bruto nacionalni dohodak, bruto nacionalni dohodak po stanovniku i sl., pri čemu se razmatraju i uvjeti (npr. razina industrijalizacije) i posljedice (društvene, političke i kulturne) ekonomskog rasta i razvoja. Spomenuti faktori rezultiraju različitim (evolucijskim) stupnjevima društvenog razvitka (tradicionalni, tranzicijski, moderni), koji se, u konačnici, temelje na različitim stupnjevima i obrascima društvene diferencijacije, specijalizacije i integracije/adaptacije strukturnih i kulturnih komponenata unutar širega društvenog sustava (Parsons, 1991; Abercrombie, Hill i Turner, 1994; Karajić, 2000). Slijedom toga, modernizacija zemalja koje zaostaju u razvoju ovisi ponajprije o uspješnosti implementiranja složenih zapadnih tehnologija (kao uvjeta gospodarskog rasta), kao i o prevladavanju tradicionalnih društvenih i kulturnih struktura inkompatibilnih sa suvremenim gospodarskim razvojem.
} 
verzificirajućim učincima, ono što ostaje imanentno svim modernizacijskim procesima je rastuća organizacijska i institucionalna kompleksnost društva koja se na individualnoj razini manifestira u vidu transformacije društvenih veza (Durkheim, 1972; Inglehart i Welzel, 2007). Točnije, napredujuća društvena birokratizacija i širenje tržišnih odnosa (tržišno posredovana podjela rada) dugoročno zadržavaju tendenciju da potiču individualizam i sekularizaciju, da potkopavaju tradicionalni moral i kolektivna vjerovanja i da time smanjuju prijašnju osnovu društvenog zajedništva. Sukladno tome društveni se odnosi temelje sve manje na pripisanim sociokulturnim karakteristikama pojedinaca i skupina (vjerska i/ili etnička pripadnost, društveni status i sl.), a sve više na uzajamno usuglašenim (pravno posredovanim) interesima (Weber, 1972; Durkheim, 1972; Habermas, 1995). U konačnici, sve veća podjela rada i prateća diferencijacija društvenih funkcija imaju za posljedicu diferencijaciju društvene svijesti i porast kulturne heterogenosti, što uključuje i promjenu društvenih vrijednosti (Berger i Luckmann, 1995).

Fokusirajući upravo ovaj vrijednosni aspekt modernizacijskih promjena u daljnjem ćemo tekstu prikazati stajalište R. Ingleharta, vjerojatno najutjecajnijega suvremenog teoretičara koji adresira ovu problematiku (Štulhofer i Kufrin, 1996; Cifrić, 1996; Karajić, 2000). Prema Inglehartu razvoj od predindustrijskih društava oskudice prema postindustrijskim društvima obilja korelira u prvoj fazi s vrijednosnom transformacijom od duhovno-religioznih prema sekularno-racionalnim vrijednostima, a u drugoj s prijelazom od materijalističkih prema tzv. postmaterijalističkim vrijednostima (Inglehart, 1997; Inglehart i Baker, 2000). Kao i drugi autori koji su se bavili ovom problematikom (usp. Durkheim, 1972; Weber, 1972; Parsons, 1991; Habermas, 1995) i Inglehart ističe da moderni socioekonomski razvoj utječe na slabljenje tradicionalnih društvenih vrijednosti, osobito onih vezanih uz odnose među rodovima, obitelj i religiju, a u korist svjetonazorskog racionalizma i društvenog pluralizma. No istodobno naglašava da potkopavanje tradicionalnih i dominaciju sekularno-racionalnih vrijednosti prati razvoj dvaju novih tipova vrijednosnih orijentacija. Preciznije, prijelaz od tradicionalnog prema modernom industrijskom društvu obilježava prioritet ekonomskog rasta i dominacija materijalističkih vrijednosti, dok kasniji razvoj postindustrijske ekonomije utemeljene na znanju karakterizira rastuća važnost individualnog izbora, potrebe za samoizražavanjem i kvalitete života izražene kroz tzv. postmaterijalističke vrijednosti (Inglehart, 1977, 1997). ${ }^{6}$

\footnotetext{
${ }^{6} \mathrm{Na}$ razini institucionalnih struktura Inglehart razvoj postmaterijalističkih vrijednosti objašnjava smanjivanjem funkcionalne efikasnosti hijerarhijskih birokratskih organizacija karakterističnih za industrijski tip društva te njihovom sve manjom prihvaćenošću u javnosti (Inglehart, 1997).
} 
Prema Inglehartu prihvaćanje postmaterijalističkih vrijednosti proistječe iz specifičnih socijalizacijskih iskustava (socialization hypothesis), tj. iz odrastanja u društvima ekonomskog blagostanja i sigurnosti koja pojedince oslobađaju egzistencijalnih briga za opstanak (vezanih primjerice uz nezaposlenost, zdravstvenu zaštitu ili uvjete stanovanja $)^{7}$ i omogućuju im zadovoljavanje potreba višeg reda (Inglehart, 1977, 1997; Inglehart i Norris, 2003; v. Štulhofer i Kufrin, 1996; Karajić, 2000; Maldini, 2005). ${ }^{8}$ U takvim uvjetima materijalizam, tj. isticanje važnosti ekonomske i fizičke sigurnosti, nasljeđuje postmaterijalizam kao vrijednosna orijentacija usmjerena samoaktualizaciji i autonomiji na individualnoj razini, odnosno redukciji i decentralizaciji autoriteta (političkih, religijskih i dr.) na socijetalnoj razini. Drugim riječima, prijelaz prema postmaterijalističkim vrijednostima karakterizira zadovoljenost osnovnih egzistencijalnih potreba većine stanovništva i prebacivanje prioriteta od pitanja ekonomske i fizičke sigurnosti na pitanja individualne autonomije, kvalitete života i samoizražavanja. S druge pak strane, privremeno ili trajno neprihvaćanje postmaterijalističkih vrijednosti Inglehart objašnjava individualnom i/ili kolektivnom izloženošću posljedicama materijalne ili sigurnosne oskudice (scarcity hypothesis) do koje dolazi u uvjetima društvenih nemira, rata ili gospodarskih kriza. Budući da pojedinac najveću subjektivnu vrijednost pridaje resursima u kojima oskudijeva, u spomenutim društvenim uvjetima (oskudice) može doći do ponovnog jačanja ili stabiliziranja materijalističkih vrijednosnih orijentacija.

Kad je riječ o vrijednosnim tipovima u Hrvatskoj, istraživanja pokazuju da su socioekonomski uvjeti tranzicijskog razdoblja, uključujući naslijeđe tradicije i politički poticane procese retradicionalizacije, pogodovali razvoju materijalističkih kao i oživljavanju predmodernih vrijednosti i vrijednosnih orijentacija (Maldini, 2005; usp. Labus, 2000). O tome, među ostalim, svjedoči istraživanje vrijednosti mladih u Hrvatskoj neposredno prije i tijekom tranzicije (Radin, 1988, 2002, 2007) koje pokazuje da mladi u promatranom razdoblju sve više privilegiraju vrijednosti privatnosti i individualne afirmacije, dok razmjerno nisko vrednuju ciljeve čije ostvarenje zahtijeva znatniji politički ili društveni angažman. ${ }^{9}$

\footnotetext{
${ }^{7}$ Ovakav razvoj došao je do punog izražaja u razdoblju ekonomskog prosperiteta Zapada nakon Drugoga svjetskog rata praćenog uspostavom moderne države blagostanja (Inglehart, 1997).

${ }^{8}$ Inglehart svoju socijalizacijsku hipotezu temelji na Maslovljevoj teoriji hijerarhijskog zadovoljenja potreba, prema kojoj potrebe višeg reda ne mogu biti realizirane ako nisu zadovoljene potrebe nižeg reda (Inglehart, 1977).

${ }^{9} »[\mathrm{M}]$ ladi svoju budućnost sve više vide kao cilj koji se može postići isključivo oslanjajući se na svoje vlastite snage i na podršku obitelji i bližnjih, uz veliko nepovjerenje prema institucijama društva, posebno onim političkim« (Radin, 2002: 76).
} 
Najveći vrijednosni pomaci u istraživanjima iz tranzicijskog razdoblja (u odnosu na istraživanje iz 1986.) odnose se na porast preferencije vrijednosti materijalnog položaja, samosvojnosti i profesionalnog uspjeha, kao i vrijednosti koje se vežu uz tradiciju, ponajprije nacionalnost i vjeru. U kasnijem razdoblju uočeno je također čvršće vezanje privatnosti uz tradicionalne vrijednosti vjere i nacije. Na snažan porast materijalističkih vrijednosti upućuju i istraživanja studentske populacije iz prvoga tranzicijskog razdoblja i tijekom rata (Leburić i Tomić-Koludrović, 1996). Do sličnih zaključaka dolaze istraživanja vrijednosti opće populacije iz istog razdoblja, u kojima se, s jedne strane, utilitarizam i materijalno bogaćenje ubrajaju među dominantne vrijednosti hrvatskoga tranzicijskog društva (Županov, 1995), dok se s druge ističe obnova tradicionalnih vrijednosnih obrazaca (Labus, 2000; Maldini, 2005) i prateći porast etnocentričkih orijentacija združenih s naglašenim patrijarhalizmom i autoritarizmom (Ilišin, 1998).

No istodobno dio istraživanja iz istog razdoblja upućuje na zaključak da proces vrijednosnih promjena u Hrvatskoj nije bio ni jednodimenzionalan ni jednosmjeran (Maldini, 2005). Primjerice, u istraživanjima u kojima se koristio Inglehartov koncept vrijednosnih promjena, ${ }^{10}$ znatan dio ispitanika uz materijalističke vrijednosti iskazuje i pristajanje uz njima suprotne postmaterijalističke vrijednosne stavove i orijentacije (Štulhofer i Kufrin, 1996; Karajić, 2000). Opisana situacija prisutna je u istraživanju odnosa postmaterijalističkih vrijednosti i ekološke osjetljivosti građana (Štulhofer i Kufrin, 1996) provedenog u okviru projekta Svjetskog istraživanja vrijednosti - Hrvatska 1995. Autori polaze od hipoteze o većoj učestalosti proekološkog ponašanja i stavova kod ispitanika sklonijih "postmaterijalističkim « vrijednostima te ispitanike dijele u tri skupine: »postmaterijalisti« $(10,8 \%)$, »materijalisti« $(38,2 \%)$ i »mješoviti« vrijednosni tip (51\%). Dobiveni podaci pokazuju da su u usporedbi s materijalistima, postmaterijalisti skloniji ekološkim oblicima ponašanja, ekološkom altruizmu i angažiranju u ekološkim udrugama te se, sukladno tome, ekološka osjetljivost identificira kao dio "postmaterijalističkoga" vrijednosnog sklopa. Da postmaterijalističke vrijednosti u ovome razdoblju nisu odbačene kao nepoželjne pokazuje i Karajićeva (2000) analiza vrijednosnih struktura hrvatskoga društva. I tu se ukazuje na tri zasebna vrijednosna tipa (materijalisti - 16,7\%, mješoviti tip - 63,7\%, postmate-

\footnotetext{
${ }^{10}$ Iako se u istraživanjima društvenih vrijednosti i vrijednosnih orijentacija u Hrvatskoj po pravilu ispitivao i odnos tradicionalnih i modernističkih vrijednosnih preferencija, do devedesetih se godina 20. stoljeća u tu svrhu nije koristio Inglehartov koncept »materijalističkih« i »postmaterijalističkih« vrijednosti (Karajić, 2000).
} 
rijalisti - 18,8\%), pri čemu ispitanici bliži postmaterijalističkim vrijednostima iskazuju veći stupanj pristajanja uz vrijednosti individualne autonomije, izrazitije proekološko ponašanje, veću sklonost demokratičnosti, imaju manje povjerenja u državotvorne i demokratske institucije, izražavaju manju političku apatiju, kao i izrazitiju nesklonost državnom i političkom paternalizmu. Iako posve jednoznačna sučeljenost nije zabilježena, u najvećem broju dimenzija materijalisti se pokazuju kao suprotstavljeni postmaterijalistima, dok se ispitanici mješovitog tipa rjeđe grupiraju uz postmaterijaliste, a češće uz materijaliste.

Opisani podaci upućuju da u razdoblju obilježenom tranzicijskim nedaćama i autoritarnim političkim iskustvima u Hrvatskoj nije došlo do zaustavljanja modernizacijskih tokova i odbacivanja postmaterijalističkih vrijednosti. Umjesto jednoznačnog razvoja bilo koje vrste, postoje naznake svojevrsne pluralizacije tradicionalnih, materijalističkih i postmaterijalističkih vrijednosnih orijentacija, s mogućnošću hibridizacije vrijednosnih struktura u tzv. »mješovite tipove« (Cifrić, 1996). Na ovome se tragu primjerice mogu tumačiti rezultati istraživanja životnih stilova mladih u Hrvatskoj devedesetih godina 20. stoljeća, koja pokazuju istodobno postojanje životnih stilova koji se temelje i na kolektivističkim i na individualističkim vrijednostima (Tomić-Koludrović i Leburić, 2001).

\section{Obrasci rodnih uloga u Hrvatskoj}

Kao sustav društveno očekivanih i inkorporiranih shema razumijevanja, vrednovanja i djelovanja rodne ${ }^{11}$ se uloge tradicionalno konstituiraju oko patrijarhalne podjele na javnu mušku (sudjelovanje u profesionalnom i političkom životu) i privatnu žensku sferu (briga za kućanstvo i obitelj) (Fraser, 1995; Galić, 2002). Spomenuta podjela strukturira nejednaku raspodjelu društvenih statusa i šansi između muškaraca i žena (Galić, 2002) i odgovorna je za činjenicu što se u patrijarhalnim društvima rad za plaću smatra manje važnim za ženin društveni identitet od njezina obavljanja kućanskih dužnosti (Massey, Hahn i Sekulić, 1995). Iako postoje više i manje patrijarhalna društva (Hofstede, 1991; Inglehart i Norris, 2003), općenito vrijedi da se žene češće zapošljavaju u manje prestižnim zanimanjima te su u prosjeku slabije plaćene od svojih muških kolega, dok su istodobno neproporcionalno opterećene kućanskim poslovima i brigom za djecu (Castells, 2000; Topolčić, 2001; Giddens, 2007).

\footnotetext{
${ }^{11}$ Dok se pojam spola odnosi na fizičke ili biološke razlike između muškaraca i žena, pojam roda označava društvenu konstrukciju ovih razlika. U tom smislu rodne uloge i identiteti nisu izravna posljedica bioloških razlika, nego se društveno izgrađuju i socijaliziraju na biološkoj osnovi (Maynard, 1999).
} 
Istraživanja o stanju u Hrvatskoj prije i poslije osamostaljenja potvrđuju ovo »rodno načelo« (Fraser, 1995) u društvenom pozicioniranju žena i muškaraca. Podaci za Jugoslaviju pokazuju da je, unatoč egalitarnoj politici koja je proklamirala emancipaciju žena kroz zapošljavanje, većina žena radila na razmjerno slabije plaćenim poslovima u specifičnim sektorima poput obrazovanja, zdravstva, tekstilne industrije ili trgovine (Massey, Hahn i Sekulić, 1995). Da, usprkos pomacima u javnoj sferi, oficijelne proklamacije o rodnoj ravnopravnosti nisu odgovarale društvenoj stvarnosti potvrđuje stabilnost patrijarhalnih struktura i vrijednosti. Javno proklamirana egalitarna ideologija u praksi nije zadirala u odnose u obitelji. Štoviše, privatna domena ostala je u osnovi nedirnuta od strane socijalističkih politika te se općenito smatralo da ženama pripada primarna odgovornost za brigu o kućanstvu i odgoju djece (Brunnbauer, 2000). Drugim riječima, usto što ih je većina bila zaposlena, na žene je i dalje otpadao najveći dio obiteljskih dužnosti. ${ }^{12}$

U tranzicijskom razdoblju u Hrvatskoj obrasci rodnih podjela iz socijalističkog razdoblja dodatno su se produbili. Društveno raslojavanje i masovno osiromašenje srednjih slojeva društva, porast nezaposlenosti koji osobito pogađa žene, kao i smanjena socijalna davanja države doveli su do ekonomskih pritisaka za povlačenjem žena iz javnoga života i njihovim okretanjem kućanskim poslovima (Topolčić, 2001; Tomić-Koludrović i Petrić, 2007). Osim ekonomskih pritisaka, u tranzicijskom se razdoblju pojavljuju i ideologijski pritisci na društveni položaj žena. U javnosti prevladavajući nacionalistički diskurs te porast utjecaja Crkve u javnome životu stvaraju političko ozračje u kojem dominiraju zahtjevi za jačanjem (neo) patrijarhalnih vrijednosti i normi te za »povratkom« žena-majki u njihovo "prirodno« obiteljsko okružje (Brunnbauer, 2000; Galić, 2000; Tomić-Koludrović i Kunac, 2000; Topolčić, 2001).

Iako je opisana »domestikacija« žena imala znatne ekonomske i društvene posljedice u Hrvatskoj i drugim tranzicijskim zemljama (Brunnbauer, 2000), ona je istodobno bila u raskoraku s modernizacijskom tezom o razvojnom potkopavanju tradicionalnih rodnih uloga. Potonju izražavaju Inglehart i Norris (2003) ističući da modernizacija sa sobom nosi razvoj prema egalitarnijim rodnim ulogama pri čemu »ljudski razvoj donosi promjene u stavovima prema rodnoj jednakosti u gotovo svakom društvu koje prolazi kroz različite oblike modernizacije povezane s ekonomskim

\footnotetext{
${ }^{12}$ Podaci iz spomenutog razdoblja za Jugoslaviju pokazuju da je ukupno radno opterećenje žena u prosjeku iznosilo šezdeset do sedamdeset sati tjedno, od čega se dvadeset do trideset odnosilo na neplaćene poslove u kući i brigu o djeci, tj. na »drugu smjenu« (BrajdićVuković, Birkelund i Štulhofer, 2007).
} 
razvojem« (Inglehart i Norris, 2003: 10; usp. Brajdić-Vuković, Birkelund i Štulhofer, 2007). Budući da Hrvatska nije izolirana od društvenih i ekonomskih tokova zapadnoga razvijenog svijeta (Cifrić, 1996; Karajić, 2000; Brajdić-Vuković, Birkelund i Štulhofer, 2007) može se postaviti pitanje u kakvom su međusobnom odnosu tranzicijski pritisci za jačanjem tradicionalnih rodnih uloga s dugoročnim modernizacijskim utjecajima na vrijednosne promjene.

\section{Cilj i hipoteze}

Cilj je istraživanja provjeriti postoje li specifični obrasci u vrijednosnim orijentacijama srednjoškolaca u tranzicijskoj Hrvatskoj koji bi korespondirali s vrijednosnim obrascima u suvremenim razvijenim društvima.

H1: Iako je tranzicijsko razdoblje u Hrvatskoj pogodovalo razvoju i oživljavanju materijalističkih i tradicionalističkih vrijednosti, istraživanja pokazuju (Štulhofer i Kufrin, 1996; Karajić, 2000; Maldini, 2005) da takav slijed nije rezultirao odbacivanjem vrijednosti individualne autonomije. Sukladno tome, očekuje se da su vrijednosne orijentacije srednjoškolaca u Hrvatskoj na tragu osnovnoga modernizacijskog obrasca, što znači da osim tradicionalnih $i$ materijalističkih, postoje i postmaterijalističke vrijednosne orijentacije.

H2: Sukladno osnovnom modernizacijskom modelu pretpostavlja se da i razvijenost regija u kojima mladi žive i odrastaju utječe na njihove vrijednosne preferencije. Očekuje se da su individualističke, odnosno postmaterijalističke, vrijednosti zastupljenije kod srednjoškolaca iz razvijenije Primorsko-goranske županije, dok su tradicionalne i materijalističke vrijednosti prihvaćenije kod srednjoškolaca iz manje razvijene Ličko-senjske županije.

H3: S obzirom na uvriježenost tradicionalnih rodnih podjela u društvu iz socijalističkog razdoblja kao i na ekonomske i ideologijske pritiske na društveni položaj žena iz tranzicijskog razdoblja, očekuju se razlike $u$ vrijednosnim preferencijama srednjoškolaca prema rodnom kriteriju, gdje djevojke više preferiraju tradicionalne vrijednosti (vjerski legitimirana uloga žene-majke koja brine za kućanstvo i obitelj), a mladići materijalističke vrijednosti (maskulina uloga u čijem je središtu sudjelovanje u profesionalnom i političkom životu).

H4: Zbog uvriježenosti tradicionalnih rodnih podjela u društvu i obuhvatnosti tranzicijskih pritisaka na društveno pozicioniranje žena, očekuje se da su razlike u prihvaćanju pojedinih vrijednosnih orijentacija između muških $i$ ženskih ispitanika unutar manje razvijene $i$ jače razvijene regije, veće od istih razlika između regija. 


\section{Metoda}

\subsection{Sudionici}

U istraživanju je sudjelovalo 1830 učenica i 1641 učenik svih srednjih škola u Primorsko-goranskoj i Ličko-senjskoj županiji. U Ličko-senjskoj županiji ispitani su svi učenici koji su se na dan ispitivanja nalazili u školi, dok je u Primorsko-goranskoj županiji ispitan reprezentativni stratificirani uzorak učenika svih razreda svih srednjih škola. Postupak odabira uzorka sastojao se $\mathrm{u}$ tome da je na osnovi podataka o ukupnom broju učenika $u$ svakom razredu u svakoj školi određen slučajni uzorak od $20 \%$ učenika za svaki razred u svakoj školi. ${ }^{13}$ Tako je osigurana proporcionalna zastupljenost učenica i učenika svih razreda i svih tipova škola. Broj ispitanika prema županiji i spolu je prikazan u Tablici 1 .

Tablica 1. Broj ispitanika u Primorsko-goranskoj i Ličko-senjskoj županiji

\begin{tabular}{|l|r|r|c|}
\hline & $L S Z ̌$ & $P G Z ̌$ & Ukupno \\
\hline Djevojke & 527 & 1303 & 1830 \\
\hline Mladići & 492 & 1149 & 1641 \\
\hline Ukupno & 1019 & 2452 & 3471 \\
\hline
\end{tabular}

U uzorku je bilo $26,3 \%$ učenika gimnazijskih programa, $45,4 \%$ učenika četverogodišnjih strukovnih škola i $28,1 \%$ učenika trogodišnjih strukovnih škola.

\subsection{Upitnik}

Primijenjeni upitnik pod nazivom »Kako si?« služi za praćenje pojavnosti rizičnih ponašanja srednjoškolaca u širem psihosocijalnom kontekstu. U sklopu upitnika korištena je i ljestvica za ispitivanje sustava vrijednosti mladih koja se sastoji od trinaest tvrdnji. Zadatak sudionika bio je procijeniti koliko su ponuđene vrijednosne tvrdnje za njih u životu važne. Vrijednosne tvrdnje su uglavnom preuzete iz longitudinalnog istraživanja vrijednosti mladih u Hrvatskoj (Radin, 1988, 2002, 2007). U svrhu ravnomjernije pokrivenosti vrijednosnog kontinuuma od tradicionalnih preko materijalističkih do postmaterijalističkih vrijednosti, izvornoj bateriji dodane su tvrdnje za samospoznaju, ljubav i solidarnost. Korištene vrijednosne tvrdnje reprezentiraju sljedeće vrijednosne dimenzije: samosvojnost, hedonizam, ljubav, profesionalni uspjeh, političko potvrđivanje, medijski uspjeh,

\footnotetext{
${ }^{13}$ Za određivanje slučajnog uzorka sudionika korišten je internetski servis Research Randomizer (http://www.randomizer.org).
} 
društveni položaj, materijalni položaj, samospoznaju, nacionalnost, solidarnost, obitelj i privatnost te vjeru.

Procjenjivalo se na ljestvici slaganja od četiri stupnja (0 - nikada, 1 rijetko; 2 - često; 3 - vrlo često).

\subsection{Postupak}

Ispitivanje je provedeno u svibnju 2003. godine u svim srednjim školama u dvjema županijama. Podržano je od županijskih jedinica Zavoda za javno zdravstvo i odobreno od nadležnih osnivača škola u županijama. Ispitivanje je provedeno u skladu s Etičkim kodeksom istraživanja s djecom (2003). Učenici su bili upoznati s ciljevima istraživanja i s time da je sudjelovanje anonimno i dragovoljno te da mogu odustati od sudjelovanja kad to požele. Niti jedan sudionik nije napustio ispitivanje.

Upitnik su u skupinama do 25 učenika na standardizirani način primjenjivali uvježbani ispitivači - studenti.

\subsection{Pregled analize podataka}

Izračunata je hijerarhija ispitanih vrijednosti i njihova faktorska struktura. Rodne razlike $\mathrm{u}$ hijerarhiji vrijednosti testirane su neparametrijskim MannWhitneyevim U-testom. Faktorska struktura vrijednosti utvrđena je eksploratornom analizom glavnih komponenti s ortogonalnom varimax rotacijom. Izračunate su pouzdanosti ekstrahiranih faktora (Cronbachov $\alpha$ ). Istražene su regionalne i rodne razlike u vrijednostima srednjoškolaca s pomoću dvosmjernih analiza varijance (regija $\mathrm{x}$ spol). Rezultati analize varijance podrobnije su provjereni Duncanovim post-hoc postupkom za utvrđivanje specifičnih razlika u procjenama vrijednosti ispitanih podskupina sudionika. Statističke su analize provedene s pomoću statističkog paketa Statistica 9.1 (StatSoft Inc., Tulsa, OK, USA).

\section{Rezultati i rasprava}

\subsection{Hijerarhije vrijednosti: frekvencijska analiza}

Sustav vrijednosti srednjoškolaca ispitan je s 13 vrijednosnih tvrdnji za koje su ispitanici trebali procijeniti koliko su one za njih u životu važne.

U Tablici 2 prikazani su postoci odgovora samo za najviši stupanj ljestvice (»vrlo često«), jer smatramo da odgovori u ovoj kategoriji najbolje odražavaju postojanost i subjektivnu važnost vrijednosnih stavova. 
Tablica 2. Procijenjene vrijednosti prema rangu i postotku

\begin{tabular}{|l|c|c|c|}
\hline Vrijednosti & Ukupno (\%) & $\begin{array}{c}\text { Djevojke } \\
\text { Rang (\%) }\end{array}$ & $\begin{array}{c}\text { Mladići } \\
\text { Rang (\%) }\end{array}$ \\
\hline 1. Profesionalni uspjeh & 56,7 & $2(62,4)$ & $1(50,4)$ \\
\hline 2. Samosvojnost & 54,9 & $3(60,2)$ & $2(48,9)$ \\
\hline 3. Samospoznaja & 51,1 & $1(62,8)$ & $6(38,1)$ \\
\hline 4. Obitelj i privatnost & 47,7 & $4(55,3)$ & $4(39,1)$ \\
\hline 5. Ljubav & 45,3 & $5(50,7)$ & $3(39,3)$ \\
\hline 6. Hedonizam & 42,4 & $6(45,7)$ & $5(38,6)$ \\
\hline 7. Solidarnost & 30,3 & $7(37,3)$ & $9(22,4)$ \\
\hline 8. Društveni položaj & 26,4 & $8(24,0)$ & $7(28,9)$ \\
\hline 9. Materijalni položaj & 23,2 & $9(19,2)$ & $8(27,5)$ \\
\hline 10. Medijski uspjeh & 13,2 & $11(8,7)$ & $10(18,3)$ \\
\hline 11. Vjera & 11,6 & $10(11,3)$ & $12(11,9)$ \\
\hline 12. Nacionalnost & 8,7 & $12(4,8)$ & $11(13,0)$ \\
\hline 13. Političko potvrđivanje & 4,0 & $13(2,2)$ & $13(6,0)$ \\
\hline
\end{tabular}

(ukupno $-\mathrm{N}=3471 ;$ djevojke $-\mathrm{N}=1830 ;$ mladići $-\mathrm{N}=1641$ )

Podaci iz Tablice 2 pokazuju da se navedene vrijednosti prema njihovoj važnosti za ispitanike ugrubo mogu podijeliti u dvije skupine. U gornjem dijelu tablice (rangovi 1-6) nalaze se dobro prihvaćene vrijednosti individualne afirmacije, autonomije i privatnosti (profesionalni uspjeh, samosvojnost, samospoznaja, obitelj, ljubav, hedonizam), dok se u dijelu slabije prihvaćenih vrijednosti (rangovi 7-13) nalaze individualno-kompetitivne (društveni i materijalni položaj, medijski uspjeh, političko potvrđivanje) i društveno-tradicijske vrijednosti (solidarnost, vjera, nacionalnost).

Usporedba rangova pojedinih vrijednosti u uzorku djevojaka i mladića provedena je s pomoću neparametrijskog Mann-Whitneyevog U-testa. Test pokazuje da ne postoji statistički značajna razlika u hijerarhiji ispitanih vrijednosti među djevojkama i mladićima $(M-W U=75 ; z=0,46 ; p=0,65)$.

Podaci upućuju na zaključak da i djevojke i mladići razmjerno bolje prihvaćaju vrijednosti koje simboliziraju individualni integritet i autonomiju pojedinca, dok istodobno razmjerno slabije procjenjuju općedruštvene i tradicijske vrijednosti, tj. vrijednosti koje simboliziraju sadašnji i prošli život u zajednici. Kad je riječ o prihvaćanju individualnih vrijednosti, primjetno je da individualizacija primarno označava individualni rast (profesionalni uspjeh, samosvojnost, samospoznaja) i kvalitetu života (ljubav, hedonizam) u privatnom okruženju (obitelj), a tek sekundarno poprima kompetitivni karakter (postizanje društvenog i materijalnog položaja, medijski uspjeh, političko potvrđivanje). 
Opisani rezultati potvrđuju trend sve zamjetnijeg povlačenja mladih $u$ svijet privatnosti, odnosno njihova usporednog odmicanja od društvenih autoriteta i zadanih ciljeva i vrijednosti (Radin, 2002, 2007). U negativnom smislu spomenuto nagnuće prema individualizaciji i privatnosti osobito dolazi do izražaja u gotovo potpunom ignoriranju politike kao poželjnog oblika društvenosti.

\subsection{Struktura vrijednosti}

$\mathrm{S}$ ciljem određivanja strukture ispitanih vrijednosti, matrica korelacija između vrijednosnih tvrdnji podvrgnuta je faktorskoj analizi. Provedena je analiza glavnih komponenti uz Guttman-Kaiserov kriterij ekstrakcije i ortogonalnu varimax rotaciju. U Tablici 3 prikazana je matrica glavnih komponenti originalnih tvrdnji. Ekstrahirane su tri glavne komponente koje zajedno objašnjavaju 49,99\% varijance.

Tablica 3. Matrica glavnih komponenti

\begin{tabular}{|l|r|r|r|}
\cline { 2 - 4 } \multicolumn{1}{l|}{} & \multicolumn{3}{c|}{ Komponenta } \\
\cline { 2 - 4 } \multicolumn{1}{l|}{} & \multicolumn{1}{c|}{1} & \multicolumn{1}{c|}{3} \\
\hline Moć i posjedovanje & & & \\
\hline $\begin{array}{l}\text { Postati medijski poznat (u sportu, glazbi i sl.) (Medijski } \\
\text { uspjeh) }\end{array}$ &, 66 &, 06 &, 02 \\
\hline $\begin{array}{l}\text { Baviti se politikom, imati političku moć (Političko } \\
\text { potvrđivanje) }\end{array}$ &, 66 &,- 04 &,- 02 \\
\hline Iskazivati svoju nacionalnu pripadnost (Nacionalnost) &, 64 &,- 14 &, 24 \\
\hline Doći na važan položaj, imati moć (Društveni položaj) &, 63 &, 43 &,- 06 \\
\hline Imati puno novaca i lijepih stvari (Materijalni položaj) &, 61 &, 35 &,- 15 \\
\hline Autonomija i samorealizacija & & & \\
\hline $\begin{array}{l}\text { Biti svoj gospodar i baviti se onim što želim } \\
\text { (Samosvojnost) }\end{array}$ &, 03 &, 69 &, 11 \\
\hline $\begin{array}{l}\text { Dobro se zabavljati bez obzira na to što misle drugi } \\
\text { (Hedonizam) }\end{array}$ &, 05 &, 68 &,- 06 \\
\hline Imati uspjeha u ljubavnom životu (Ljubav) &, 09 &, 63 &, 20 \\
\hline $\begin{array}{l}\text { Biti uspješan u struci, u svom poslu (Profesionalni } \\
\text { uspjeh) }\end{array}$ &, 07 &, 58 &, 34 \\
\hline Obitelj i tradicija & & & \\
\hline Pomagati drugim ljudima (Solidarnost) &,- 02 &, 15 &, 76 \\
\hline Živjeti mirno u krugu obitelji (Obitelj i privatnost) &,- 05 &, 15 &, 72 \\
\hline Živjeti u skladu s učenjem svoje vjere (Vjera) &, 37 &,- 14 &, 67 \\
\hline Bolje upoznati samoga sebe (Samospoznaja) &,- 14 &, 38 &, 53 \\
\hline
\end{tabular}


Tri glavne komponente ili faktora vrijednosti jasno opisuju skupine tvrdnji koje imaju slično semantičko značenje i koje se mogu identificirati kao (1) faktor »moći i posjedovanja«, (2) faktor »autonomije i samorealizacije« i (3) faktor »obitelji i tradicije«.

Prvi faktor je saturiran s pet vrijednosnih tvrdnji (medijski uspjeh, političko potvrđivanje, nacionalnost, društveni položaj, materijalni položaj). Uključene vrijednosti naglašavaju individualnu korist i kompetitivne društvene odnose, pri čemu se sfera politike očekivano vezuje uz nacionalne vrijednosti, no jednako tako i uz medijski uspjeh, društveni položaj i ostvarivanje materijalne dobiti. Opisane vrijednosti potvrđuju rezultate prethodnih istraživanja (usp. Radin, 2002) prema kojima se nacionalna pripadnost, politika i vlast u tranzicijskom kontekstu percipiraju kao uobičajeni kanali za postizanje materijalne sigurnosti, a koje se, barem na simboličnoj razini, povezuju i s medijskim uspjehom. U tom smislu ovaj faktor opisuje potrebu za moći $i$ posjedovanjem.

Drugi je faktor primarno saturiran s četirima vrijednosnim stavovima (samosvojnost, hedonizam, ljubav, profesionalni uspjeh), pri čemu su svi usmjereni na aspiracije i želje pojedinca s naglašenom individualističkom komponentom (»svoj gospodar«, »bez obzira na to što misle drugi«, »ljubavni život«, »svoj posao«). Kako je riječ o prostoru individualnih sloboda i osobnih značenja, ovaj smo faktor nazvali faktorom autonomije i samorealizacije pojedinca.

Treći je faktor primarno saturiran s četirima vrijednostima (solidarnost, obitelj i privatnost, vjera, samospoznaja). Pritom se vjera i vjerski konotirane vrijednosti samospoznaje i solidarnosti povezuju s privatnošću i obiteljskim vrijednostima $i$ tako tvore tipičan sklop tradicijsko-konzervativnih vrijednosti, zbog čega smo ovaj sklop varijabli nazvali faktorom obitelji $i$ tradicije.

Izračunati koeficijenti pouzdanosti (Cronbachov $\alpha$ ) izlučenih faktora upućuju na relativno nisku internu konzistenciju ljestvica. Pouzdanost ljestvica iznosi: (1) moć i posjedovanje, $\alpha=0,67$; (2) autonomija i samorealizacija, $\alpha=0,65$; (3) obitelj i tradicija, $\alpha=0,64$. S obzirom na to da se ljestvice sastoje od samo četiriju, odnosno pet tvrdnji, ova se pouzdanost ipak može smatrati prihvatljivom za istraživačke svrhe. ${ }^{14}$

Izlučena vrijednosna struktura na tragu je Inglehartova modernizacijskog modela unutar kojega nalazimo tradicionalne, materijalističke i

\footnotetext{
${ }^{14}$ Ukupni rezultati na pojedinim faktorima određeni su zbrojem procjena na svim tvrdnjama koje čine faktor. Faktorski rezultati su radi lakše interpretacije linearno transformirani na ljestvice od 0 do 100. Ovakva transformacija omogućuje neposrednu usporedbu rezultata ljestvica s nejednakim brojem čestica (tvrdnji).
} 
postmaterijalističke vrijednosne orijentacije. Faktor koji smo nazvali faktorom tradicije $i$ obiteljskih vrijednosti, a koji sadržava tradicijsku komponentu u kombinaciji s vrijednostima obitelji i privatnosti, po svojoj je strukturi usmjeren prema prošlosti i prema njegovanju vjerskih, nacionalnih i obiteljskih tradicija. Kombinacija tradicije i privatnosti odlika su konzervativnog svjetonazora u kojemu kao središnja vrednota figurira očuvanje postojećih sociokulturnih tradicija, odnosno osporavanje društvenih promjena. S druge strane, faktor nazvan moć i posjedovanje analogan je Inglehartovim materijalističkim vrijednostima. Struktura potonjeg zasićena je vrijednostima kompetitivnog karaktera (politička moć, medijski uspjeh, utilitarno shvaćene nacionalne vrijednosti) usmjerenima postizanju materijalne i društvene sigurnosti. Nasuprot tome, faktor autonomije i samorealizacije najbliži je Inglehartovim postmaterijalističkim vrijednostima, budući da ističe ponajprije autonomiju i samoaktualizaciju pojedinca (»Biti svoj gospodar i baviti se onim što želim«) bilo na profesionalnom planu, bilo na intimnijoj razini ljubavnog života ili privatne društvenosti. Povlačenju u svijet individualnosti na ovome faktoru pridonosi i njegova (iako nešto slabija) povezanost s ciljem samospoznaje pojedinca.

Postojanje triju opisanih vrijednosnih faktora upućuje na to da su po svojim strukturnim obrascima vrijednosne orijentacije srednjoškolaca u Hrvatskoj kompatibilne s vrijednosnim tipovima karakterističnim za Inglehartov model modernizacije vrijednosti.

\subsection{Vrijednosti, rod i regionalna pripadnost: testiranje razlika}

Sukladno opisanom Inglehartovu modelu, postmaterijalističke vrijednosne orijentacije po pravilu su prihvaćenije u bogatijim i razvijenijim društvenim sredinama, dok su njima oprečne tradicionalne i materijalističke vrijednosti češće zastupljene u manje razvijenim društvima. Na tragu rečenoga, polazi se od pretpostavke da i razvijenost regija u kojima mladi žive i odrastaju može utjecati na njihove vrijednosne preferencije. U tom se smislu može očekivati da su individualističke, odnosno postmaterijalističke, vrijednosti zastupljenije kod mladih iz razvijenije Primorsko-goranske županije, dok su tradicionalne i materijalističke vrijednosti prihvaćenije kod mladih iz manje razvijene Ličko-senjske županije (hipoteza 2). Kao indikator gospodarskog razvoja županija koristi se podatak za bruto domaći proizvod u 2003. (usp. Lajić, 1991; Inglehart i Baker, 2000). 
Tablica 4. BDP za Primorsko-goransku i Ličko-senjsku županiju, 2003.

\begin{tabular}{|l|c|}
\hline Županija & BDP, mil. kn, 2003. \\
\hline Primorsko-goranska županija & 16.100 \\
\hline Ličko-senjska županija & 2449 \\
\hline
\end{tabular}

Izvor: Bruto domaći proizvod za Republiku Hrvatsku, Prostorne jedinice za statistiku 2. razine i županije od 2000. do 2006., DZSRH, 2006.

Iz podataka u Tablici 4 vidljivo je da je Primorsko-goranska županija u 2003. imala oko 6,5 puta veći bruto domaći proizvod od Ličko-senjske županije, odnosno da je Primorsko-goranska županija u tom smislu znatno gospodarski razvijenija od Ličko-senjske županije.

Osim razlika prema razvijenosti regija, u vrijednosnim preferencijama mladih očekuju se također i razlike prema rodu. Pretpostavlja se da uvriježenost tradicionalnih rodnih podjela u društvu i procesi društvene retradicionalizacije u tranzicijskome razdoblju podržavaju reprodukciju tradicionalnih predodžbi o odnosima između rodova, a time i razlike u vrijednosnim preferencijama između djevojaka i mladića (hipoteza 3). Pritom se očekuje da su razlike u prihvaćanju pojedinih vrijednosnih orijentacija između muških i ženskih ispitanika unutar manje razvijene i jače razvijene regije veće od istih razlika između regija (hipoteza 4).

Kako bi se utvrdile značajnosti razlika u procjenama važnosti triju faktora vrijednosti u uzorcima djevojaka i mladića u PGŽ i LSŽ, provedene su tri dvosmjerne $2 \times 2$ analize varijance (regija x spol). Te analize omogućuju jednostavno testiranje postavljenih hipoteza, odnosno uvid u postojanje razlika u procjenama između ispitanih podskupina ispitanika.

U nastavku su prikazani deskriptivni podaci i distribucije rezultata na trima ljestvicama vrijednosnih stavova prema regionalnoj pripadnosti (Primorsko-goranska i Ličko-senjska županija) za djevojke i mladiće.

Tablica 5. Aritmetičke sredine i standardne devijacije vrijednosnih procjena triju faktora prema regionalnoj pripadnosti ukupno i zasebno za djevojke i mladiće

\begin{tabular}{|l|c|l|r|r|c|}
\hline Vrijednosne orijentacije & Županija & \multicolumn{1}{|c|}{ Spol } & $N$ & $M$ & \multicolumn{1}{c|}{$S D$} \\
\hline \multirow{3}{*}{ Moć i posjedovanje } & \multirow{3}{*}{ PGŽ } & ukupno & 2363 & 40,57 & 19,664 \\
\cline { 3 - 6 } & & Ženski & 1259 & 37,04 & 18,299 \\
\cline { 3 - 6 } & & muški & 1104 & 44,59 & 20,390 \\
\cline { 3 - 6 } & \multirow{3}{*}{ LSŽ } & ukupno & 983 & 44,48 & 20,465 \\
\cline { 3 - 6 } & & Ženski & 515 & 41,74 & 19,579 \\
\cline { 3 - 6 } & & muški & 468 & 47,50 & 21,008 \\
\hline
\end{tabular}




\begin{tabular}{|c|c|c|c|c|c|}
\hline \multirow{6}{*}{ Autonomija $i$ samorealizacija } & \multirow{3}{*}{ PGŽ } & ukupno & 2388 & 80,88 & 15,130 \\
\hline & & ženski & 1275 & 83,44 & 12,783 \\
\hline & & muški & 1113 & 77,94 & 16,972 \\
\hline & \multirow{3}{*}{ LSŽ } & ukupno & 996 & 78,72 & 17,730 \\
\hline & & ženski & 524 & 82,27 & 15,008 \\
\hline & & muški & 472 & 74,79 & 19,608 \\
\hline \multirow{6}{*}{ Obitelj $i$ tradicija } & \multirow{3}{*}{ PGŽ } & ukupno & 2374 & 66,84 & 18,237 \\
\hline & & Ženski & 1269 & 71,20 & 15,616 \\
\hline & & muški & 1105 & 61,83 & 19,692 \\
\hline & \multirow{3}{*}{ LSŽ } & ukupno & 981 & 72,62 & 18,496 \\
\hline & & Ženski & 513 & 77,00 & 16,093 \\
\hline & & muški & 468 & 67,82 & 19,745 \\
\hline
\end{tabular}

$\mathrm{Na}$ priloženim slikama prikazane su aritmetičke sredine procjena u svim ispitanim podskupinama sudionika (regija x spol) za svaki od faktora vrijednosti, kao i rezultati dvosmjernih analiza varijance.

Slika 1. Prikaz prosječnih procjena važnosti faktora moći i posjedovanja u ispitanim podskupinama ispitanika i rezultati analize varijance

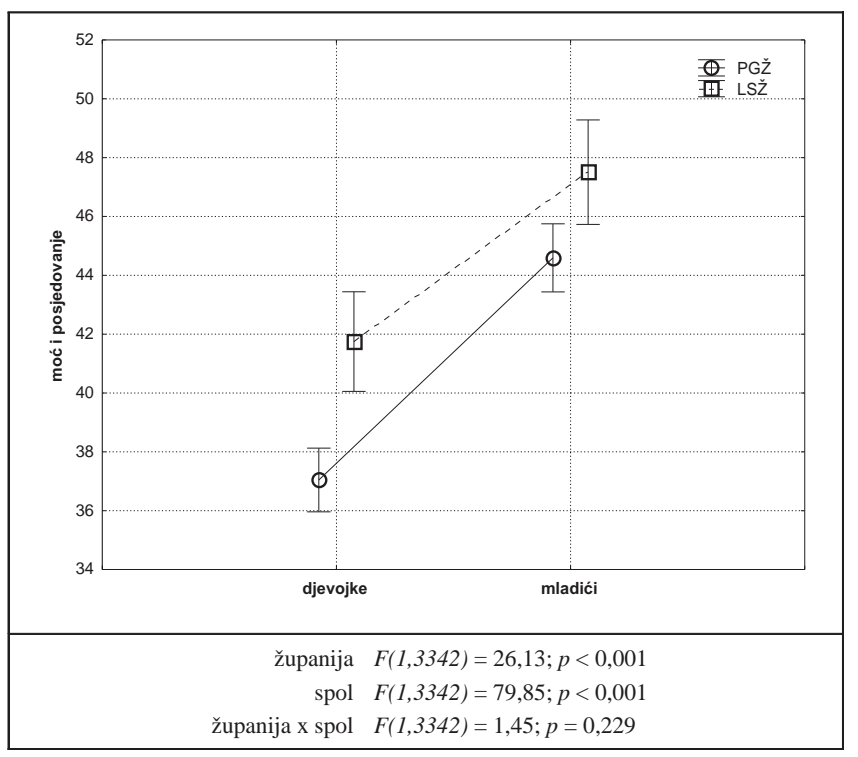

Okomite crte uz oznake aritmetičkih sredina označuju interval u kojemu se s 95\% pouzdanosti procjene nalazi aritmetička sredina populacije 
Slika 2. Prikaz prosječnih procjena važnosti faktora autonomije $i$ samorealizacije $u$ ispitanim podskupinama ispitanika i rezultati analize varijance

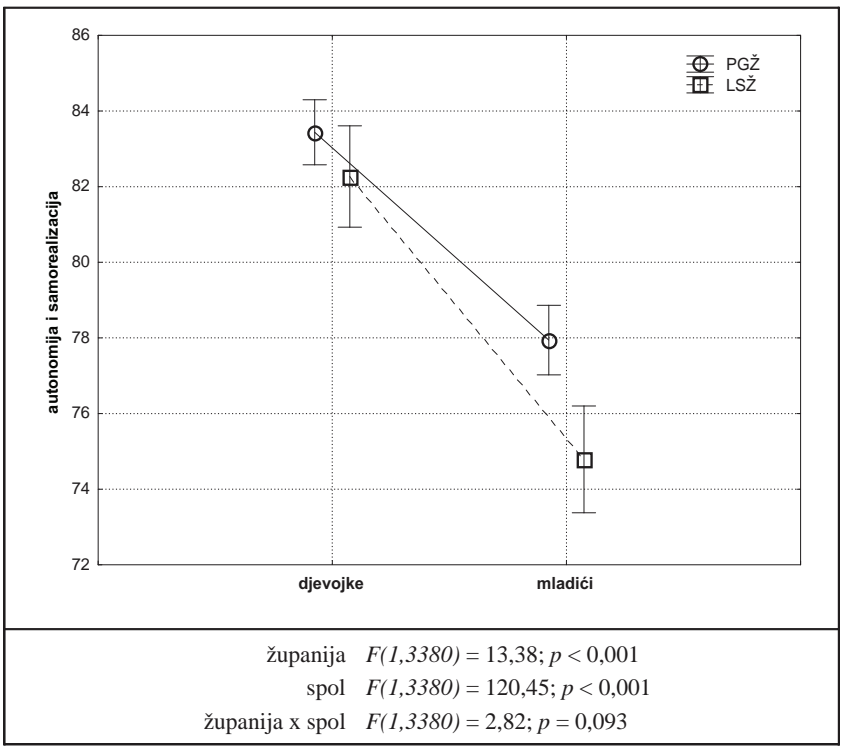

Slika 3. Prikaz prosječnih procjena važnosti faktora obitelji i tradicije u ispitanim podskupinama ispitanika i rezultati analize varijance

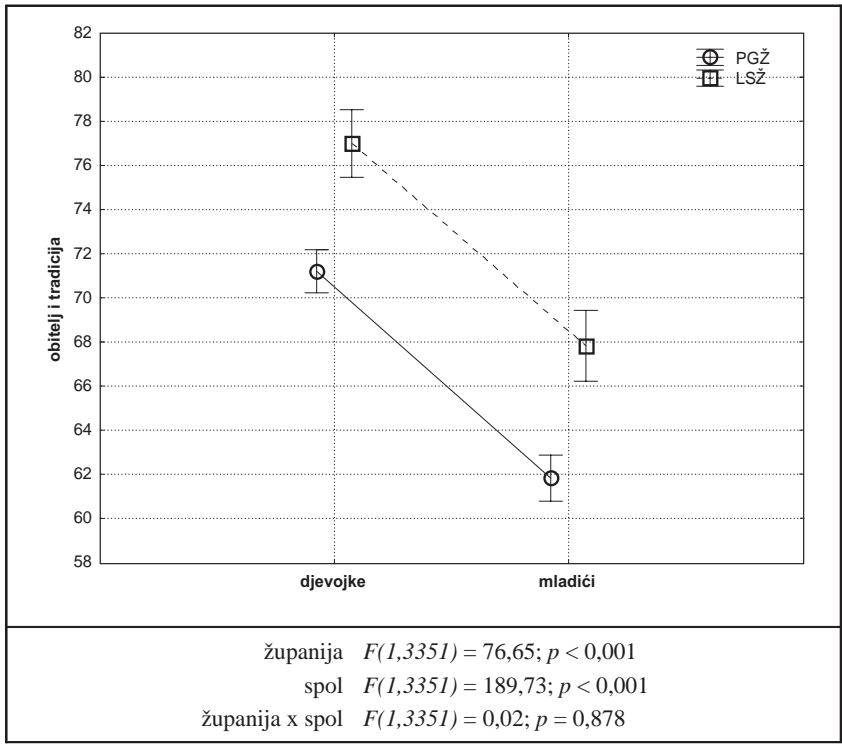


Dvosmjerne analize varijance (regija x spol) pokazuju da se djevojke i mladići u Primorsko-goranskoj i Ličko-senjskoj županiji razlikuju na svim trima faktorima vrijednosnih stavova. Statistički značajan efekt spola, odnosno roda, pokazuje se na procjenama važnosti moći $i$ posjedovanja, na procjenama važnosti autonomije $i$ samorealizacije te na procjenama važnosti obiteljskih $i$ tradicionalnih vrijednosti (vidjeti priložene F-omjere uz slike).

Također se pokazuje i statistički značajan efekt regionalne pripadnosti na procjenama važnosti moći $i$ posjedovanja, na procjenama obiteljskih $i$ tradicionalnih vrijednosti te nešto niži, ali još uvijek statistički značajan, efekt na procjenama važnosti autonomije i samorealizacije. Niti u jednoj analizi nisu utvrđeni interakcijski efekti regionalne pripadnosti i roda sudionika ispitivanja.

Provedeni post-hoc testovi višestruke usporedbe (Duncanov postupak) pokazuje da na svim trima faktorima među svim podskupinama ispitanika postoje statistički značajne razlike u procjenama, osim na faktoru autonomije $i$ samorealizacije među podskupinama djevojaka u PGŽ i djevojaka u LSŽ $(p=0,162)$. U potonjem slučaju se pokazuje da djevojke u objema županijama pridaju približno podjednaku važnost vrijednostima autonomije i samorealizacije.

Prikazani podaci u Tablici 5 i na Slikama 1-3, potvrđuju polazišnu hipotezu prema kojoj su postmaterijalističkim vrijednostima, u našem slučaju predstavljenim faktorom autonomije $i$ samorealizacije, statistički značajno skloniji učenici iz razvijenije PGŽ, dok su materijalističkim (faktor moć $i$ posjedovanje) i tradicionalnim vrijednostima (faktor obitelj $i$ tradicija) skloniji učenici iz manje razvijene LSŽ. Ovaj nalaz vrijedi kako za ukupne rezultate, tako i za pojedine skupine ispitanika prema rodu, osim u slučaju faktora autonomije i samorealizacije čijim vrijednostima, kako je istaknuto, djevojke u dvjema županijama pridaju približno podjednaku važnost. Dobiveni rezultati na tragu su osnovne pretpostavke Inglehartova transformacijskog modela prema kojemu viši stupanj ekonomskog razvoja i materijalne sigurnosti prati rastuća važnost individualnog izbora i samorealizacije pojedinca.

No kad je riječ o rodnim razlikama u vrijednosnim preferencijama dobiveni rezultati nisu jednoznačni. S jedne strane nalaz prema kojemu mladići u objema županijama statistički značajno više pozornosti pridaju materijalističkim vrijednostima, dok djevojke više preferiraju vrijednosti koje se vežu uz obitelj $i$ tradiciju potvrđuje pretpostavku o tradicionalnoj podjeli rodnih uloga na javnu mušku i privatnu žensku sferu. No, podatak da djevojke u objema županijama statistički značajno više preferiraju i vrijednosti samorealizacije i osobne autonomije upućuje da se efekt roda ne može objasniti samo djelovanjem tradicije, nego da su prisutni i opći 
razvojni čimbenici koji modificiraju njezino značenje (npr. viša opća razina obrazovanja i materijalne sigurnosti u objema županijama). Vezano uz Inglehartovu shemu tradicionalnih, materijalističkih i postmaterijalističkih vrijednosti, ovaj nalaz indicira da umjesto razvojnog prevladavanja pod određenim okolnostima može prije doći do supostojanja idealnotipski suprotstavljenih vrijednosnih orijentacija (usp. Tomić-Koludrović i Kunac, 2000).

Četvrtu testiranu hipotezu (drugu koja adresira efekt rodnih razlika) pretpostavku da su razlike u prihvaćanju pojedinih vrijednosnih orijentacija među muškim i ženskim ispitanicima unutar regija veće od razlika među djevojkama i mladićima iz različitih regija - dobiveni rezultati jasno potvrđuju. Iz prikazanih je rezultata, naime, vidljivo da su za sva tri analizirana faktora iskazane razlike u vrijednosnim preferencijama među djevojkama i mladićima unutar dviju županija statistički značajno veće od razlika među djevojkama i mladićima iz različitih regija, pri čemu na faktoru autonomije i samorealizacije i nema statistički značajne razlike među djevojkama iz PGŽ i LSŽ. Drugim riječima, djevojke iz manje razvijene LSŽ pridaju veću važnost sklopu vrijednosti autonomije i samorealizacije od mladića iz razvijenije PGŽ, unatoč tomu što u prosjeku ukupno tim vrijednostima više važnosti pridaju mladi iz razvijenije regije. Obratno, isto vrijedi za vrijednosne orijentacije koje su u prosjeku prihvaćenije kod adolescenata iz manje razvijene LSŽ. Podaci za moć $i$ autonomiju i obiteljske $i$ tradicijske vrijednosti pokazuju da prvima mladići iz PGŽ pridaju više važnosti nego što to čine djevojke iz LSŽ, dok druge više prihvaćaju djevojke iz PGŽ od mladića iz LSŽ. Opisani rezultati indiciraju da efekt roda znatno relativizira utjecaj regionalne razvijenosti na prihvaćanje vrijednosnih orijentacija, iako se, kako smo vidjeli, i sam modificira pod utjecajem potonjih. Iako strukturni čimbenici na predvidljiv način utječu na promjene vrijednosnih stavova mladih, kulturni utjecaj vezan uz tradicionalne rodne uloge $\mathrm{i}$ identitete se ne gubi, nego se razvojno adaptira $\mathrm{i}$ ostaje dominantnim i u promijenjenim društvenim okolnostima.

\section{Zaključna razmatranja}

$\mathrm{Na}$ uvodno postavljeno pitanje o tome postoje li određeni obrasci u vrijednosnim orijentacijama srednjoškolaca u tranzicijskoj Hrvatskoj koji bi korespondirali s vrijednosnim promjenama u suvremenim razvijenim društvima možemo dati potvrdan odgovor. Iz analiziranih podataka se može iščitati da srednjoškolci socijalizirani u tranzicijskom razdoblju u Hrvatskoj prihvaćaju širok raspon vrijednosnih orijentacija, pa su tako, osim očekivanih tradicijskih i materijalističkih vrijednosti, kod njih jednako tako zastupljene i vrijednosti postmaterijalističkog tipa s naglaskom na samoozbiljenju i individualnoj autonomiji. Štoviše, postmaterijalističke vrijednosti koje naglašavaju indivi- 
dualni integritet i autonomiju pojedinca ovi mladi razmjerno bolje prihvaćaju od drugih dvaju Inglehartovih vrijednosnih tipova. Budući da su društvene vrijednosti uvjetovane kako tradicijom tako i prilagodbom na strukturne uvjete, može se pretpostaviti da odsutnost ili prisutnost pojedinih vrijednosnih orijentacija upućuje i na razvojne momente promatranog društva. S modernizacijskog aspekta objašnjenje za ovako »šarenu« vrijednosnu konstelaciju može ponuditi teza prema kojoj su se modernizacijski procesi u tranzicijskom razdoblju u Hrvatskoj odvijali na više kvalitativnih razina (usp. Tomić-Koludrović i Leburić, 2001). U tom su smislu posljedice rata, opća ekonomska restrukturacija i prateća egzistencijalna nesigurnost vjerojatno pogodovali prihvaćanju tradicijskih i materijalističkih vrijednosti, dok se istodobno prihvaćanje postmaterijalističkih vrijednosti može tumačiti činjenicom da Hrvatska u isto vrijeme nije ostala izoliranom od društvenih i ekonomskih tokova i tekovina Europe i razvijenoga svijeta (Brajdić-Vuković, Birkelund i Štulhofer, 2007; Tomić-Koludrović i Petrić, 2007). Postmaterijalističke vrijednosti stoga općenito mogu biti prisutne i kao poželjne vrijednosti.

Naznačenu kompleksnost sociokulturnih transformacija u tranzicijskom razdoblju u Hrvatskoj potvrđuje testiranje razlika među različitim podskupinama srednjoškolaca (regionalna razvijenost x spol). Utvrđena statistička značajnost razlika ide u prilog Inglehartovoj tezi o korespondenciji ekonomskog razvoja s važnošću individualnog izbora i samorealizacije pojedinca, no istodobno upućuje na zaključak da spomenute promjene nisu nužno jednosmjerne. Točnije, umjesto razvojnog prevladavanja, kod određenih društvenih skupina može prije doći do kulturnog relativiziranja, odnosno supostojanja idealno suprotstavljenih vrijednosnih orijentacija. U skladu s time rezultati analize varijance indiciraju da kulturno posredovan efekt roda nadvladava utjecaj razvojnih čimbenika (regionalna razvijenost), no da se i sam modificira pod utjecajem potonjih. Na potonju tezu upućuje činjenica da djevojke u objema županijama više od mladića preferiraju i postmaterijalističke vrijednosti samorealizacije i osobne autonomije i njima suprotstavljene obiteljske i tradicijske vrijednosti.

Na individualnoj razini rodno posredovanu vrijednosnu koegzistenciju vjerojatno olakšava činjenica što i postmaterijalističke i tradicijske orijentacije predstavljaju vrijednosne sklopove u kojima je prisutan odmak od instrumentalnih i materijalističkih vrijednosnih obrazaca: bilo da je riječ o vjerski konotiranim vrijednostima introspekcije i solidarnosti bilo o vrijednostima usmjerenima emocionalnom ispunjenju i samoaktualizaciji, u obama slučajevima preferiraju se vrijednosti koje simboliziraju ekspresivne društvene odnose kao i refleksivan odnos prema životu (usp. Beutel i Marini, 1995). Šire društveno objašnjenje za trajan utjecaj roda na vrijednosnu pluraliza- 
ciju nalazimo u strukturnoj ukorijenjenosti vrijednosno-normativnih podjela vezanih uz mušku i žensku »sferu«, a koje, modernizacijskim promjenama usprkos, ostaju i dalje društveno relevantne (Fraser, 1995; Krais, 2000; Tomić-Koludrović i Kunac, 2000). U osnovi to znači da će intenzitet tih podjela, tj. njihov opseg $\mathrm{i}$ institucionalna ukorijenjenost, strukturirati društvene disparitete između muškaraca i žena i time utjecati na reprodukciju istih onih sociokulturnih distinkcija temeljem kojih su se spomenute podjele $\mathrm{i}$ same prvobitno strukturirale (Bourdieu i Wacquant, 1992). Na ovoj se točki problematika sociokulturne transformacije o kojoj govori Inglehart isprepleće s problematikom reprodukcije društvenih nejednakosti. Ovo treba imati na umu budući da se usuprotnome vrijednosna transformacija promatra kao proces s »vlastitom logikom« (Klages, 2000) koji se može ostvarivati »protiv« institucija i dominantnih društvenih podjela. $U$ tom bi se slučaju pitanje »nadoknađivanja« hrvatskih modernizacijskih zaostataka s početka teksta pretvorilo u pitanje s latentnim ideološkim/konzervativnim predznakom.

\section{LITERATURA}

Abercrombie, Nicholas, Hill, Stephen i Turner, Bryan S. (1994). The Penguin Dictionary of Sociology. 3rd ed. London: Penguin.

Armer, J. Michael i Katsillis, John (2000). »Modernization Theory«, u: Edgar F. Borgatta i Rhonda J. V. Montgomery (ur.). Encyclopedia of Sociology. 2nd ed. New York: Macmillan Reference USA, str. 1883-1888.

Berger, Peter L. i Luckmann, Thomas (1995). Modernität, Pluralismus und Sinnkrise: Die Orientierung des modernen Menschen. Gütersloh: Verl. BertelsmannStiftung.

Beutel, Ann M. i Marini, Margaret Mooney (1995). »Gender and Values«, American Sociological Review, 60 (3): 436-448.

Bourdieu, Pierre i Wacquant, Loïc J. D. (1992). An Invitation to Reflexive Sociology. Cambridge: Polity.

Brajdić-Vuković, Marija, Birkelund, Gunn Elisabeth i Štulhofer, Aleksandar (2007). »Between Tradition and Modernization: Attitudes Toward Women's Employment and Gender Roles in Croatia«, International Journal of Sociology, 37 (3): 32-53. doi:10.2753/IJS0020-76593703002

Brunnbauer, Ulf (2000). »From equality without democracy to democracy without equality? Women and transition in south-east Europe«, South-East Europe Review, 3: 151-168.

Bruto domaći proizvod za Republiku Hrvatsku, Prostorne jedinice za statistiku 2. razine $i$ županije od 2000. do 2006. (2006). Zagreb: Državni zavod za statistiku RH.

Castells, Manuel (2000). Uspon umreženog društva. Zagreb: Golden marketing.

Cifrić, Ivan (1996). »Tranzicija i transformacija: između norme i prakse«, Socijalna ekologija, 5 (2): 135-153. 
Čulig, Benjamin., Fanuko, Nenad i Jerbić, Velibor (1982). Vrijednosti i vrijednosne orijentacije mladih. Zagreb: Centar društvenih djelatnosti SSOH.

[Durkheim, Émile] Диркем, Емил (1972 [1893]). О подели друштвеног рада. Београд: Просвета.

Etički kodeks istraživanja s djecom (2003). Zagreb: Vijeće za djecu Vlade Republike Hrvatske, Državni zavod za zaštitu obitelji, materinstva i mladeži, http:// www.mobms.hr/media/15438/eticki\%20kodeks\%20objedinjeno\%20dodano.pdf.

Fraser, Nancy (1995). »From Redistribution to Recognition? Dilemmas of Justice in a 'Post-Socialist' Age«, New Left Review, 212: 68-93.

Galić, Branka (2000). »Politička kultura 'novih demokracija'«, Revija za sociologiju, 31 (3-4): 197-209.

Galić, Branka (2002). »Moć i rod«, Revija za sociologiju, 33 (3-4): 225-238.

Giddens, Anthony (2007). Sociologija. Zagreb: Globus.

Giordan, Giuseppe (2007). »Values«, u: George Ritzer (ur.). The Blackwell Encyclopedia of Sociology. Malden, Mass.: Blackwell, str. 5176-5180.

Habermas, Jürgen (1995 [1981]). Theorie des kommunikativen Handelns. Frankfurt am Main: Suhrkamp.

Hofstede, Geert (1991). Cultures and Organisations: Software of the Mind. London: McGraw-Hill.

Ilišin, Vlasta (1998). »Demokratska tranzicija u Hrvatskoj«, Sociologija sela, 36 (1-4): $27-52$.

Ilišin, Vlasta (2002). »Mladost, odraslost i budućnost«, u: Vlasta Ilišin i Furio Radin (ur.). Mladi uoči trećeg milenija. Zagreb: Institut za društvena istraživanja u Zagrebu, str. 27-46.

Ilišin, Vlasta i Radin, Furio (2002). »Društveni kontekst i metodologija istraživanja«, u: Vlasta Ilišin i Furio Radin (ur.). Mladi uoči trećeg milenija. Zagreb: Institut za društvena istraživanja u Zagrebu, str. 13-26.

Inglehart, Ronald (1977). The Silent Revolution: Changing Values and Political Styles Among Western Publics. Princeton, New Yersey: Princeton University Press.

Inglehart, Ronald (1997). Modernization and Postmodernization: Cultural, Economic, and Political Change in 43 Societies. Princeton, New Jersey: Princeton University Press.

Inglehart, Ronald i Baker, Wayne E. (2000). »Modernization, Cultural Change, and the Persistence of Traditional Values«, American Sociological Review, 65 (1): 19-51.

Inglehart, Ronald i Norris, Pippa (2003). Rising Tide: Gender Equality and Cultural Change around the World. Cambridge: Cambridge University Press.

Inglehart, Ronald i Welzel, Christian (2007). »Modernization«, u: George Ritzer (ur.). The Blackwell Encyclopedia of Sociology. Malden, Mass.: Blackwell, str. 3071-3078.

Karajić, Nenad (2000). Politička modernizacija: prilozi sociologiji hrvatskoga društva. Zagreb: Hrvatsko sociološko društvo i Zavod za sociologiju Filozofskog fakulteta u Zagrebu.

Klages, Helmut (2000) »The Silent Revolution«, u: Dirk Kaesler i Ludgera Vogt (ur.). Hauptwerke der Soziologie. Stuttgart: Alfred Kröner Verlag, str. 217-220. 
Krais, Beate (2000). »The Gender Relationship in Bourdieu's Sociology«, SubStance, 29 (3/93/): 53-67.

Labus, Mladen (2000). »Vrijednosne orijentacije u hrvatskom društvu«, Sociologija sela, 38 (1-2): 169-204.

Lajić, Ivan (1991). »Usporedna analiza gospodarskog razvitka općina Slunj i Čakovec u razdoblju 1961-1990.«, u: Milan Mesić i sur. Vanjske migracije i društveni razvitak. Zagreb: Institut za migracije i narodnosti Sveučilišta u Zagrebu, str. 78-90.

Leburić, Anči i Tomić-Koludrović, Inga (1996). »Mladi danas: drukčiji, ali isti«, Društvena istraživanja, 5 (5-6): 963-975.

Maldini, Pero (2005). »Demokratizacija i vrijednosne orijentacije u hrvatskom društvu«, Anali Hrvatskog politološkog društva, 2: 81-103.

Massey, Garth, Hahn, Karen i Sekulić, Duško (1995). »Women, Man, and the 'Second Shift' in Socialist Yugoslavia«, Gender \& Society, 9 (3): 359-379. doi:10.1177/089124395009003006

Maynard, Mary (1999). »Gender Relations«, u: Steve Taylor (ur.). Sociology: Issues and Debates. Basingstoke: Macmillan, str. 116-135.

Pantić, Dragomir (1977). »Vrednosti i ideološke orijentacije društvenih slojeva«, u: Mihailo V. Popović, Silvano Bolčić, Vesna Pešić, Milosav Janićijević i Dragomir Pantić. Društveni slojevi i društvena svest. Beograd: Centar za sociološka istraživanja, str. 269-406.

Parsons, Talcott (1991). Društva. Zagreb: August Cesarec.

Radin, Furio (1988). »Hijerarhije i strukture društvenih vrijednosti«, u: Furio Radin (ur.). Fragmenti omladine[: položaj, svijest i ponašanje mladih Hrvatske]. Zagreb: Radna zajednica Republičke konferencije Saveza socijalističke omladine Hrvatske i Institut za društvena istraživanja Sveučilišta u Zagrebu, str. 99-118.

Radin, Furio (2002). »Vrijednosne hijerarhije i strukture«, u: Vlasta Ilišin i Furio Radin (ur.). Mladi uoči trećeg milenija. Zagreb: Institut za društvena istraživanja u Zagrebu, str. 47-78.

Radin, Furio (2007). »Vrijednosti mladih Hrvata«, u: Vlasta Ilišin i Furio Radin (ur.). Mladi: problem ili resurs. Zagreb: Institut za društvena istraživanja u Zagrebu, str. 137-156.

Sztompka, Piotr (1993). The Sociology of Social Change. Oxford: Blackwell.

Štulhofer, Aleksandar i Kufrin, Krešimir (1996). »Od obilja do altruizma i druge ekološke priče: postmaterijalistički sindrom i ekološke vrijednosti u Hrvatskoj«, Socijalna ekologija, 5 (2): 171-184.

Tomić-Koludrović, Inga i Kunac, Suzana (2000). Rizici modernizacije: žene u Hrvatskoj devedesetih. Split: Stope nade.

Tomić-Koludrović, Inga i Leburić, Anči (2001). Skeptična generacija: životni stilovi mladih u Hrvatskoj. Zagreb: AGM.

Tomić-Koludrović, Inga i Petrić, Mirko (2007). »Hrvatsko društvo - prije i tijekom tranzicije«, Društvena istraživanja, 16 (4-5): 867-889.

Topolčić, Davor (2001). »Muškarci to ne rade: rodno segregirana podjela rada u obitelji«, Društvena istraživanja, 10 (4-5): 767-789. 
Weber, Max (1972 [1922]). Wirtschaft und Gesellschaft. Tübingen: Mohr. Županov, Josip (1995). Poslije potopa. Zagreb: Globus.

Županov, Josip (2002). »Predgovor«, u: Vlasta Ilišin i Furio Radin (ur.). Mladi uoči trećeg milenija. Zagreb: Institut za društvena istraživanja u Zagrebu, str. 9-12.

\title{
Regional and Gender Differences in Value Attitudes of Secondary School Pupils in Two Croatian Counties: Transition, Modernization and Change in Values
}

\author{
Saša PUZIĆ, Petar BEZINOVIĆ \\ Institute for Social Research, Zagreb, Croatia \\ puzic@idi.hr,petar@idi.hr
}

The main question raised in the paper is whether the social consequences of the "transition to capitalism" (increased social and economic stratification, the absence of a social consensus on desirable social values, etc.) has had an impact on the modernization-related lag of Croatian society at value level. In an attempt to find an answer to this question, the authors investigated the compatibility of value orientations of secondary school pupils socialised during the transition period in Croatia with value types typical for the Inglehart model of value modernization, including the differences related to gender and the regional developmental level. The investigation of value orientations was carried out on a representative, stratified sample of 3471 pupils from two Croatian counties (Lika-Senj and Primorje-Gorski Kotar). The hierarchy of the tested values and their factorial structure were examined, followed by an investigation of specific regional and gender-related differences using two-way analysis of variance. The results show that pupils socialised in the transition period in Croatia accept a wide range of value orientations, which supports the hypothesis that modernization processes in this period have taken place on several qualitative levels. Testing of the significance of the differences between various sub-groups (region $\mathrm{x}$ gender) showed that developmental factors affect the transformation of value-related attitudes of youth, but also that the culturally mediated effect of gender relativises the impact of developmental factors. The authors ascribe this situation to the permanent relevance of gender divisions in the society, which have not decreased in importance even under the circumstances of modern social changes.

Key words: transition, modernization, youth, values, regional developmental level, gender divisions, pluralisation 